\title{
The use of a pregnancy-specific antigen, chorionic somatomammotrophin, as an indicator of pregnancy in sheep
}

\author{
H. A. Robertson, J. S. D. Chan* and H. G. Friesen* \\ Animal Research Institute, Ottawa, Canada K1A 0C6, and *Department of Physiology, \\ Faculty of Medicine, University of Manitoba, Winnipeg, Canada R3E OW3
}

\begin{abstract}
Summary. Measurement of the serum concentrations of ovine chorionic sommatomammotrophin (oCS) showed that the values could be used to distinguish nonpregnant $(100 \%)$ and pregnant $(97 \%)$ ewes from Day 64 after mating. Values of oCS in non-pregnant ewes were $<5 \mathrm{ng} / \mathrm{ml}$.
\end{abstract}

\section{Introduction}

The first pregnancy test for the domesticated species of animals based upon the presence of a specific pregnancy antigen followed the finding of pregnant mare's serum gonadotrophin (Cole \& Hart, 1930a, b). The presence of the pregnancy-specific protein hormone, ovine chorionic somatomammotrophin (oCS), was first demonstrated and measured by Kelly, Robertson \& Friesen (1974) who noted a rise in concentration of this hormone between Days 60 and 100. This was subsequently confirmed by Handwerger et al. (1975, 1977), Martal \& Djiane (1977) and Chan, Robertson \& Friesen (1978). Thimonier, Bosc, Djiane, Martal \& Terqui (1977) reported that a pregnancy test based upon the presence of oCS was applicable in the ewe from Days 80 to 90 .

The present report presents data on the use of oCS as a test for pregnancy in the ewe from Day 57 of gestation.

\section{Materials and Methods}

The 199 cross-bred ewes were divided into 3 groups. Oestrus in the animals in each group was synchronized at intervals of 1 week and the ewes were bred by natural mating during exposure to the ram for 4 days. A blood sample was collected from each ewe at Day 70 (Group 1), Day 64 (Group 2) and Day 57 (Group 3) of gestation, chilled in ice-water and centrifuged at $4^{\circ} \mathrm{C}$. The serum was harvested and frozen at $-20^{\circ} \mathrm{C}$. The oCS concentration was determined by radioimmunoassay (Chan et al., 1978) using $50 \mu \mathrm{l} \mathrm{serum.} \mathrm{Ovine} \mathrm{pituitary} \mathrm{growth} \mathrm{hormone} \mathrm{and} \mathrm{ovine}$ prolactin do not cross-react with the anti-oCS serum. Similarly, several hormone preparations of pituitary or placental origin from several species showed no cross-reaction. The only samples which cross-reacted in the assay were sheep placental extracts, fetal fluids and serum. The sensitivity of the assay was $0.25 \mathrm{ng}$ oCS ( $\equiv 5 \mathrm{ng} \mathrm{oCS} / \mathrm{ml}$ serum) and the intra- and inter-assay coefficients of variation were 10.5 and $8.2 \%$ respectively. All estimates found to be between 5 and $20 \mathrm{ng} / \mathrm{ml}$ were repeated. Ewes having detectable levels of oCs of $\geqslant 5.0 \mathrm{ng} / \mathrm{ml}$ were diagnosed as pregnant. Pregnancy or otherwise was confirmed at the time of parturition. 


\section{Results}

These are shown in Table 1.

Group 1 . Only 1 ewe was wrongly diagnosed as pregnant at Day 70 and she had a marginally detectable level of $5.2 \mathrm{ng} \mathrm{oCS} / \mathrm{ml}$.

Group 2. There was little difference in the accuracy of prediction at Day 64 and that at Day 70. The wrongly diagnosed ewe had an oCS concentration of $>100 \mathrm{ng} / \mathrm{ml}$ at the time of diagnosis and it is probable that this ewe subsequently aborted.

rable 1. The percentage accuracy of prediction of pregnancy and non-pregnancy in ewes at Days 70,64 and 57 of gestation based on the appearance or absence of oCS

\begin{tabular}{llll}
\hline & \multicolumn{3}{c}{ Day of gestation } \\
\cline { 2 - 4 } & \multicolumn{1}{c}{70} & \multicolumn{1}{c}{64} & \multicolumn{1}{c}{57} \\
\hline No. of ewes tested & 65 & 62 & 72 \\
No. diagnosed non-pregnant & 35 & 33 & 34 \\
No. non-pregnant & $35(100 \%)$ & $33(100 \%)$ & $34(100 \%)$ \\
oCS conc. (ng/ml) & $<5$ & $<5$ & $<5$ \\
No. diagnosed pregnant & 30 & 29 & 38 \\
No. pregnant & $29(97 \%)$ & $28(97 \%)$ & $33(87 \%)$ \\
oCS conc. (ng/ml) & $27 \cdot 1->100$ & $15 \cdot 4->100$ & $8 \cdot 3->100$ \\
\hline
\end{tabular}

Group 3. Although the accuracy of prediction for non-pregnant ewes still remained at $100 \%$ at Day 57 , there was less accuracy in predicting the ewes which would subsequently lamb. The 5 ewes diagnosed as pregnant but which failed to lamb had oCS concentrations of 5.6, 13.9, 15.4, 16.0 and $30.4 \mathrm{ng} / \mathrm{ml}$ and so were likely to have aborted. The lowest concentration for oCS $(8.3$ $\mathrm{ng} / \mathrm{ml}$ ) in a ewe confirmed to be pregnant in all the groups was observed in this group.

\section{Discussion}

Chemical methods for pregnancy diagnosis in the ewe have been based either on the change of concentration of some normal constituent in body fluids, e.g. progesterone (Robertson \& Sarda, 1971; Shemesh, Ayalon \& Mazor, 1979) or upon the presence of a pregnancy-specific substance (Cerini, Findlay \& Lawson, 1976; Morton, Nancarrow, Scaramuzzi, Evison \& Clunie, 1979; Martal, Lacroix, Loudes, Saunier \& Winterberger-Torrès, 1979).

An early pregnancy test based on plasma progesterone concentration at Day 16,17 or 18 (Robertson \& Sarda, 1971) has been widely used for checking pregnancy in experimental animals when the day of breeding is known. However, under commercial conditions, the ewes are generally exposed to the ram over a period encompassing 2 cycles, i.e. 35 days, and the precise day of breeding is not known for individual ewes. As a management tool in commercial sheep productiomand under certain experimental conditions it would be advantageous to be able to detect pregnancy during mid-gestation. The present data confirm the reliability of the presence of oCS as a pregnancy test when used for blood samples collected from all ewes, exposed to a ram, 64 days or later after the removal of the ram.

In the present study there were 5 cases $(2.5 \%)$ of fetal loss, i.e. failure to lamb, despite unequivocal oCS levels indicative of pregnancy, between Day 57 and parturition. Information as to when fetal loss as distinct from embryonic loss occurs in sheep could be obtained by carrying out a pregnancy test based on blood progesterone concentration at Day 17 followed by serum oCS determinations at regular intervals from Day 64 until just before parturition.

This paper is contribution No. 835 from the Animal Research Institute. 


\section{References}

Cerini, M.E., Findlay, J.K. \& Lawson, R.A.S. (1976) Pregnancy-specific antigens in the sheep: application to the diagnosis of pregnancy. J. Reprod. Fert. 46, 65-69.

Chan, J.S.D., Robertson, H.A. \& Friesen, H.G. (1978) Maternal and fetal concentrations of ovine placental lactogen measured by radioimmunoassay. Endocrinology 102, 1606-1613.

Cole, H. H. \& Hart, G.H. (1930a) The potency of blood serum of mares in progressive stages of pregnancy in effecting the sexual maturity of the immature rat. $A \mathrm{~m}$. J. Physiol. 93, 57-68.

Cole, H.H. \& Hart, G.H. (1930b) Sex hormones in the blood serum of mares. II. The sera of mares from the 222 nd day of pregnancy to the first heat period postpartum. Am. J. Physiol. 94, 597-603.

Handwerger, S., Maurer, W.F., Crenshaw, M.C., Hurley, T., Barrett, J. \& Fellows, R.E. (1975) Development of the sheep as an animal model to study placental lactogen physiology. J. Pediatr. 87, 1139-1143.

Handwerger, S., Crenshaw, C., Maurer, W.F., Barrett, J., Hurley, T.W., Golander, A. \& Fellows, R.E. (1977) Studies on ovine placental lactogen secretion by homologous radioimmunoassay. $J$. Endocr. 72, 2734.
Kelly, P.A., Robertson, H.A. \& Friesen, H.G. (1974) Temporal pattern of placental lactogen and progesterone secretion in sheep. Nature, Lond. 248, $435-436$.

Martal, J. \& Djiane, J. (1977) Mammotrophic and growth promoting activities of a placental hormone in sheep. J. Steroid Biochem. 8, 415-417.

Martal, J., Lacroix, M.-C. Loudes, C., Saunier, M. \& Winterberger-Torrès, S. (1979) Trophoblastin, an antiluteolytic protein present in early pregnancy in sheep. J. Reprod. Fert. 56, 63-73.

Morton, H., Nancarrow, C.D., Scaramuzzi, R.J., Evison, B.M. \& Clunie, G.J.A. (1979) Detection of early pregnancy in sheep by the rosette inhibition test. $J$. Reprod. Fert. 56, 75-80.

Robertson, H.A. \& Sarda, I.R. (1971) A very early pregnancy test for mammals: its application to the cow, ewe and sow. J. Endocr. 49, 407-419.

Shemesh, M., Ayalon, N. \& Mazor, T. (1979) Early pregnancy diagnosis in the ewe, based on milk progesterone levels. J. Reprod. Fert. 56, 301-304.

Thimonier, J., Bosc, M., Djiane, J., Martal, J. \& Terqui, M. (1977) Hormonal diagnosis of pregnancy and number of fetuses in sheep and goats. In Proc. Symp. Management of Reproduction in Sheep and Goats, pp. 79-88. University of Wisconsin.

Received 13 July 1979 